\title{
Comparative Analysis of the Feasibility Inpari IR Nutri Zinc Paddy Farming with Other Varieties in Nanggulan Sub-district Kulon Progo District
}

\author{
Galuh Nafiatunnisa* \\ Department of Agribusiness, Faculty of Agriculture, Universitas Muhammadiyah Yogyakarta, \\ Indonesia, 55183
}

\begin{abstract}
This study aims to determine the average cost, revenue, income, and profit of Inpari IR Nutri Zinc, Ciherang, and Inpari 42 Paddy farming and to determine of comparison the average of the feasibility of Inpari IR Nutri Zinc Paddy farming with Ciherang and Inpari 42 Paddy farming in Nanggulan Sub-district, Kulon Progo District. The sampling method is a cluster sampling method with a non-proportional for determining the number of respondents in Jatisarono Village, Nanggulan Sub-district, Kulon Progo District with a total sample of 60 farmers. The average cost per $1,000 \mathrm{~m}^{2}$ of Inpari IR Nutri Zinc, Ciherang, and Inpari 42 Paddy farming in Nanggulan Sub-district respectively is IDR 2,001,362, IDR 1,937,718, and IDR 2,024,216. The average revenue per $1,000 \mathrm{~m}^{2}$ of Inpari IR Nutri Zinc, Ciherang, and Inpari 42 Paddy farming respectively is IDR 2,179,575, IDR $2,545,940$, and IDR 2,551,111. The average income per $1,000 \mathrm{~m}^{2}$ of Inpari IR Nutri Zinc, Ciherang, and Inpari 42 Paddy farming respectively is IDR 817,141 , IDR $1,171,901$, and IDR $1,176,587$. The average profit per $1,000 \mathrm{~m}^{2}$ of Inpari IR Nutri Zinc, Ciherang, and Inpari 42 Paddy farming respectively is IDR 178,213 , IDR 608,222 , and IDR 526,895. The average feasibility of Inpari IR Nutri Zinc Paddy farming in terms of R/C, land productivity, labor productivity, and capital productivity are still lower than the feasibility of Ciherang and Inpari 42 Paddy farming.
\end{abstract}

\section{Introduction}

The provision of high-quality and sustainable paddy seeds of superior varieties can assist farmers to increase paddy production yields [1]. The high yielding of paddy varieties has superior characteristics and can assist farmers to reduce the risk of production failure, such as resistance to certain plant-disturbing organisms. In addition, high-yielding paddy varieties have high productivity potential numbers.

Inpari IR Nutri Zinc is a New Superior Variety (VUB) from the Indonesian Center for Paddy Research (BBPadi) in Sukamandi, West Java Province. The paddy variety was

* Corresponding author: galuh.n.fp17@mail.umy.ac.id 
released in 2019 along with a Decree (SK) from the Minister of Agriculture. The superiorities of Inpari IR Nutri Zinc are in terms of productivity potential, pest and disease resistance, and $\mathrm{Zn}$ content in paddy. The paddy plant has potential productivity of 9.98 tons/ha. Moderately resistant to brown plant hopper biotypes 1 and 2, bacterial leaf blight of pathotype III, tungro inoculum Garut, and Purwakarta. It is also resistant to blast ras of 033, 073, and 133. In addition, Inpari IR Nutri Zinc has a high potential for Zn content which can reach $34.51 \mathrm{ppm}$ with an average of $29.54 \mathrm{ppm}$ [2]. The high content of $\mathrm{Zn}$ is used by the government as a stunting prevention program. From 2021 to 2024 the Ministry of Agriculture will expand the planting of Inpari IR Nutri Zinc [3]. Seeds of the variety have been spread to 17 provinces. One of them is the Province of the Special Region of Yogyakarta in Kulon Progo District.

Kulon Progo District is one of the districts a special location for accelerating stunting reduction [4]. The results of the Nutrition Status Monitoring (PSG) show that in 2017 stunting cases were $16.38 \%$, while in 2018 there was a decrease in stunting cases with a total of $14.31 \%$ cases. The distribution of Inpari IR Nutri Zinc paddy in Kulon Progo District is one of the efforts to support the decrease in stunting cases in Kulon Progo District. The highest paddy producer in 2018 in Kulon Progo District, namely in Nanggulan Sub-district with total paddy production reaching 13.95 thousand tons [5]. The Sub-district also includes where the distribution of Inpari IR Nutri Zinc paddy cultivation.

Table 1. Paddy Production and Land Area in Kulon

Progo District in Each Sub-district in 2018

\begin{tabular}{|c|c|c|}
\hline Sub-district & Paddy Production (tons) & Land Area (ha) \\
\hline Temon & 11,374 & 1,741 \\
\hline Wates & 9,098 & 1,397 \\
\hline Panjatan & 11,858 & 1,838 \\
\hline Galur & 13,065 & 2,042 \\
\hline Lendah & 7,052 & 1,079 \\
\hline Sentolo & 12,032 & 1,829 \\
\hline Pengasih & 7,996 & 1,224 \\
\hline Kokap & 897 & 137 \\
\hline Girimulyo & 5,752 & 880 \\
\hline Nanggulan & 13,951 & 2,185 \\
\hline Kalibawang & 12,003 & 1,849 \\
\hline Samigaluh & 9,989 & 1,500 \\
\hline
\end{tabular}

Source: [5]

Paddy farming of Inpari IR Nutri Zinc variety has high prospects in terms of the potential advantages of productivity, nutrition, and pest resistance. However, in terms of feasibility, the paddy variety is not yet known. In addition, how is the comparison of the feasibility of Inpari IR Nutri Zinc paddy farming seen from the R/C, land productivity, labor productivity, and capital productivity with other varieties of paddy farming in Nanggulan Sub-district, namely Ciherang variety and Inpari 42 variety.

This study aims to determine the average cost, revenue, income, and profit of Inpari IR Nutri Zinc, Ciherang, and Inpari 42 paddy farming and to determine a comparison of the average feasibility of Inpari IR Nutri Zinc Paddy farming with Ciherang and Inpari 42 Paddy farming in Nanggulan Sub-district, Kulon Progo District.

The research results of Ismail et al. [6] in Blang Situngkoh Village, Pulo Aceh Subdistrict, Aceh Besar District, the production of Ciherang paddy farming is 4.50 tons/ha or reaches $64.29 \%$ of the potential production of 7 tons/ha. The results of Susanti et al. [7] in Warujayeng Village, Tanjunganom Sub-district, Nganjuk District, the Ciherang paddy 
farming produces a profit of 13,949,100 IDR/ha/season with $\mathrm{R} / \mathrm{C}$ feasibility of 1.68/ha/season. Based on the research results of Nasution et al. [1], the net income and feasibility of Ciherang paddy farming are the highest among the 3 superior paddy varieties in Labuhanbatu District. The average net income is IDR 14,416,111/ha/season with R/C feasibility of $2.29 /$ ha/planting season.

The results of Susanti et al. [7] in Warujayeng Village, Tanjunganom Sub-district, Nganjuk District, Inpari 42 paddy farming has a profit of 21,277,600 IDR/ha/season with $\mathrm{R} / \mathrm{C}$ feasibility of $2.01 / \mathrm{ha} / \mathrm{season}$. The research results of Ismail et al. [6] in Blang Situngkoh Village, Pulo Aceh Sub-district, Aceh Besar Regency, the production of Inpari 42 paddy farming is 5.20 tons/ha or reaches $49.15 \%$ of the potential production of 10.58 tons/ha. In addition, the Inpari 42 paddy farming receives an income of IDR 23,400,000/ha with $\mathrm{R} / \mathrm{C}$ feasibility of $1.22 / \mathrm{ha}$.

Table 2. Paddy Plant Characteristics

\begin{tabular}{|l|c|c|c|}
\hline \multicolumn{1}{|c|}{ Parameter } & $\begin{array}{c}\text { Inpari IR } \\
\text { Nutri Zinc }\end{array}$ & Ciherang & Inpari 42 \\
\hline Plant age (days) & 115 & $116-125$ & 112 \\
\hline Height recommendation (mdpl) & $0-600$ & $0-500$ & $0-600$ \\
\hline Plant height (cm) & 95 & $91-106$ & 93 \\
\hline Plant shape & upright & upright & upright \\
\hline Flag leaf & upright & upright & upright \\
\hline Grain shape & slender & slender and long & slender \\
\hline Grain color & straw yellow & clean yellow & straw yellow \\
\hline $\begin{array}{l}\text { Grain weight per 1,000 items } \\
\text { (gram) }\end{array}$ & 24.60 & $27-28$ & 24.41 \\
\hline Productivity potential (tons/ha) & 9.98 & 7 & 10.58 \\
\hline Average production (tons/ha) & 6.21 & $5-7$ & 7.11 \\
\hline
\end{tabular}

Source: [2]

\section{Method}

The method used in this research is descriptive analysis. The descriptive analysis method aims to identify and describe trends and variations in the population, also creating new measures of key phenomena [8]. In this study, identification, and description of the identity of the respondent farmers, costs, revenues, incomes, and profits are carried out and determine the comparison of the farming feasibility of three paddy varieties. The research is carried out in Jatisarono Village, Nanggulan Sub-district, Kulon Progo District with the determination of the research location carry out purposively. The data used is data for one paddy planting season in Jatisarono Village in 2020, September-December

Table 3. Number of Farmers and Sample

\begin{tabular}{|c|l|c|c|}
\hline No & Paddy Variety & Number of Farmers & Number of Respondents \\
\hline 1 & Inpari IR Nutri Zinc & 46 & 20 \\
\hline 2 & Ciherang & 214 & 20 \\
\hline 3 & Inpari 42 & 68 & 20 \\
\hline \multicolumn{2}{|c|}{ Total } & $\mathbf{3 2 8}$ & $\mathbf{6 0}$ \\
\hline
\end{tabular}

The total population based on the survey results is approximately 328 farmers. Sampling is done by probability sampling technique with the cluster sampling method. Determinations of the number of respondents are carried out in a non-proportional and obtain a sample of 60 farmers. 
Primary data are obtained directly through interviews and observation. Interviews are conducted using a tool in the form of a questionnaire containing questions that asked respondents to obtain data.

The methods of analysis are carried out with a mathematical formula as follows:

\subsection{Cost}

$$
T C=T E C+T I C
$$

Statement:

$\mathrm{TC}=$ Total Cost (IDR)

TEC $=$ Total Explicit Cost (IDR)

TIC $=$ Total Implicit Cost (IDR)

[9]

\subsection{Revenue}

Statement:

$$
T R=Y x P y
$$

$\mathrm{TR}=$ Total Revenue (IDR)

$\mathrm{Y}=$ Number of Production $(\mathrm{kg})$

Py $=$ Price $($ IDR $/ \mathrm{kg}$ )

[10]

\subsection{Income/Net Revenue}

$N R=T R-T E C$

Statement:

NR = Net Revenue/Income (IDR)

$\mathrm{TR}=$ Total Revenue (IDR)

TEC $=$ Total Explicit Cost (IDR)

[9]

\subsection{Profit}

$$
\pi=\mathrm{TR}-\mathrm{TC}
$$

Statement:

$\Pi \quad=$ Profit (IDR)

$\mathrm{TR}=$ Total Revenue (IDR)

$\mathrm{TC}=$ Total Cost (IDR)

[9]

\section{$2.5 \mathrm{R} / \mathrm{C}$}

$$
R / C=\frac{T R}{T C}
$$

Statement:

$\mathrm{TR}=$ Total Revenue (IDR)

$\mathrm{TC}=$ Total Cost (IDR)

[10] 
Provision:

If $\mathrm{R} / \mathrm{C}<1$, paddy farming is not feasible to cultivate

If $\mathrm{R} / \mathrm{C}>1$, paddy farming is feasible to cultivate

If $\mathrm{R} / \mathrm{C}=1$, paddy farming is at the break-even point

\subsection{Land Productivity}

\section{Statement:}

$$
\text { Land Productivity }=\frac{\text { NR-TKDN Cost-BMS }}{\text { Land Area }}
$$

$$
\begin{array}{ll}
\text { NR } & =\text { Net Revenue/Income (IDR) } \\
\text { TKDK Cost } & =\text { Family Labor Cost (IDR) } \\
\text { BMS } & =\text { Own Capital Interest Cost (IDR) } \\
{[9]} &
\end{array}
$$

\section{Provision:}

Land productivity $<$ cost of renting land, paddy farming is not feasible to cultivate

The land productivity $\geq$ cost of renting land, paddy farming is feasible to cultivate.

\subsection{Labor Productivity}

Statement:

$$
\text { Labor Productivity }=\frac{\text { NR }-S L S-B M S}{\text { HKO TKDK }}
$$

$$
\begin{array}{ll}
\text { NR } & =\text { Net Revenue/Income (IDR) } \\
\text { SLS } & =\text { Own Land Rent Cost (IDR) } \\
\text { BMS } & =\text { Own Capital Interest Cost (IDR) } \\
\text { HKO TKDK } & =\text { Number of Working Days of Family Labor (HKO) } \\
{[9]} &
\end{array}
$$

Provision:

Labor productivity $<$ farm labor wage per day, paddy farming is not feasible to cultivate Labor productivity $\geq$ farm labor wage per day, paddy farming is feasible to cultivate.

\subsection{Capital Productivity}

Statement:

$$
\text { Capital Productivity }=\frac{\text { NR-SLS }- \text { TKDK Cost }}{\text { TEC }} \times 100 \%
$$

$$
\begin{array}{ll}
\text { NR } & =\text { Net Revenue/Income (IDR) } \\
\text { SLS } & =\text { Own Land Rent (IDR) } \\
\text { Cost TKDK } & =\text { Family Labor Cost (IDR) } \\
{[9]} &
\end{array}
$$

The hypothesis of this study is suspected that there are differences in average income, profit, and feasibility between Inpari IR Nutri Zinc paddy farming, Ciherang paddy farming, and Inpari 42 paddy farming in terms of $\mathrm{R} / \mathrm{C}$, land productivity, labor productivity, and capital productivity in Nanggulan Sub-district, Kulon Progo District. Therefore, the hypothesis test in this study using the SPSS application tool consists of 2 stages, namely the One Way Anova test then followed by the Least Significant Difference (LSD) test using a significance level of $10 \%$. 


\section{Result and discussion}

\subsection{Farmer Identity}

Table 4. Farmer Identity

\begin{tabular}{|l|l|l|l|}
\hline \multirow{2}{*}{ Farmer Identity } & \multicolumn{1}{c|}{ Paddy Variety } \\
\cline { 2 - 4 } & \multicolumn{1}{|c|}{$\begin{array}{c}\text { Inpari IR } \\
\text { Nutri Zinc }\end{array}$} & \multicolumn{1}{c|}{ Ciherang } & \multicolumn{1}{c|}{ Inpari 42 } \\
\hline Gender & $\begin{array}{l}95 \% \text { Male, 5\% } \\
\text { Female }\end{array}$ & $\begin{array}{l}90 \% \text { Male, 10\% } \\
\text { Female }\end{array}$ & $85 \%$ Male, 15\% Female \\
\hline $\begin{array}{l}\text { Average of Age (years } \\
\text { old) }\end{array}$ & 61.7 & 64.5 & 64.6 \\
\hline Education Level & $\begin{array}{l}55 \% \text { Senior } \\
\text { High School }\end{array}$ & $\begin{array}{l}55 \% \text { Elementary } \\
\text { School }\end{array}$ & $\begin{array}{l}40 \% \text { Elementary School, 40\% } \\
\text { Senior High School }\end{array}$ \\
\hline $\begin{array}{l}\text { Average of Farming } \\
\text { Experience (years) }\end{array}$ & 32.85 & 37.05 & 32 \\
\hline $\begin{array}{l}\text { the majority of family } \\
\text { members }\end{array}$ & 3 & 2 & 2 \\
\hline $\begin{array}{l}\text { Average of Land area } \\
\left(\mathrm{m}^{2}\right)\end{array}$ & $2,107.5$ & 2,156 & $1,972,5$ \\
\hline
\end{tabular}

Table 4 shown based on gender, male farmers are mostly in Inpari IR Nutri Zinc paddy farming as much as 95 percent and female farmers are mostly in Inpari 42 paddy farming as much as 15 percent. Inpari IR Nutri Zinc paddy farming is mostly conducted by male farmers, so the energy devoted to farming tends to be greater.

The majority of farmers who cultivate Inpari IR Nutri Zinc are in the productive age group or the range of 15-64 years as much as 55 percent. So that the Inpari IR Nutri Zinc paddy farming tends to be maximally cultivated by farmers. This is because farmers who have a productive age have stronger physical abilities than farmers who have a nonproductive age. Meanwhile, the majority of Ciherang and Inpari 42 paddy farmers are of non-productive age or more than 64 years. Respectively 65 percent and 55 percent.

The education level of Inpari IR Nutri Zinc paddy farmers in Nanggulan Sub-district is relatively high. Because the majority of farmers have a high school education level or equivalent as much as 55 percent and 10 percent of farmers with a college education level. Therefore, the mindset and attitude in making decisions in farming activities are good. While the majority of farmers who cultivate Ciherang paddy with an elementary education level of 55 percent and the majority of farmers who cultivate Inpari 42 paddy with an elementary and high school education level or equivalent are 40 percent respectively.

The majority of Inpari IR Nutri Zinc paddy farmers have farming experience for 44-53 years as much as 30 percent and the average experience of farmers is 32.85 years. However, the average farming experience for Inpari IR Nutri Zinc paddy farmers is still lower than the average farming experience for Ciherang paddy farmers, which is 37.05 years. Meanwhile, the average farming experience of Inpari 42 paddy farmers is 32 years.

The majority of Inpari IR Nutri Zinc paddy farmers have 3 family members as much as 35 percent. Meanwhile, the majority of Ciherang and Inpari 42 paddy farmers have 2 family members, 40 and 50 percent, respectively. Ciherang and Inpari 42 paddy farmers are old so that their children already have their own families and are no longer dependents. Meanwhile, Inpari IR Nutri Zinc paddy farmers are still in their productive age. Therefore, they still have more dependents than farmers who are old. That way, the income that can be set aside for farming capital is also less because the cost of living expenses tends to be 
higher. However, the more members in the family, the better to support farming. This is because family members can also assist in the process of farming activities.

The average land area of Inpari IR Nutri Zinc paddy farmers in Nanggulan District is moderate at $2,107.5 \mathrm{~m}^{2}$. Because the average land area of Inpari IR Nutri Zinc paddy farmers is between the Ciherang and Inpari 42 paddy farmers' average land area of 2,156 $\mathrm{m}^{2}$ and $1,972.5 \mathrm{~m}^{2}$, respectively.

The majority of Inpari IR Nutri Zinc paddy farmers use their land to cultivate paddy as much as 60 percent. The number of farmers who use leased land the most is Inpari 42 paddy farmers as much as 20 percent. Meanwhile, the number of farmers who use land with the production-sharing system the most is Ciherang paddy farmers as much as 40 percent.

The type of occupation other than farming conducted by the farmers of Inpari IR Nutri Zinc paddy, Ciherang paddy, and Inpari 42 paddy is mostly as a breeder. Manure produced from livestock can be used by farmers as fertilizer to support the growth of rice plants and can increase paddy production higher.

\subsection{Explicit Cost}

Explicit costs are costs that are incurred in real by farmers in farming activities. Explicit costs include costs for seeds, fertilizers, pesticides, non-family labor (TKLK), depreciation of equipment, land rental costs, production sharing, and other costs.

Table 5. Average Explicit Cost Per 1,000 $\mathrm{m}^{2}$ Per Paddy Planting Season

\begin{tabular}{|l|r|r|r|}
\hline \multirow{2}{*}{ Cost Type } & \multicolumn{2}{c|}{ Cost (IDR) } \\
\cline { 2 - 4 } & $\begin{array}{c}\text { Inpari IR Nutri } \\
\text { Zinc }\end{array}$ & \multicolumn{1}{c|}{ Ciherang } & \multicolumn{1}{c|}{ Inpari 42 } \\
\hline Seed & 6,338 & 46,106 & 14,164 \\
\hline Solid Fertilizer & 195,537 & 159,311 & 207,685 \\
\hline Liquid Fertilizer & 11,976 & 3,256 & 11,067 \\
\hline Pesticide & 3,798 & 11,703 & 7,164 \\
\hline Non-family Labor & 623,432 & 398,274 & 584,697 \\
\hline $\begin{array}{l}\text { Depreciation of } \\
\text { Equipment }\end{array}$ & 34,803 & 31,623 & 17,837 \\
\hline Land Rental & 57,222 & 37,500 & 65,833 \\
\hline Production sharing & 255,515 & 567,850 & 294,950 \\
\hline Other Costs & 173,813 & 118,416 & 171,127 \\
\hline Total & $\mathbf{1 , 3 6 2 , 4 3 4}$ & $\mathbf{1 , 3 7 4 , 0 3 9}$ & $\mathbf{1 , 3 7 4 , 5 2 4}$ \\
\hline
\end{tabular}

Based on the results of the study, Table 5 shows that the highest average explicit cost in Inpari 42 paddy farming is 1,374,524 IDR. The average number of seeds used in Inpari IR Nutri Zinc paddy farming is $3.94 \mathrm{~kg}$ and the average cost of seeds in Inpari IR Nutri Zinc paddy farming is the lowest among the 2 other paddy varieties. Meanwhile, the use of seeds in Ciherang and Inpari 42 paddy farming is $4.44 \mathrm{~kg}$ and $5.58 \mathrm{~kg}$, respectively. The government assists farmers in the form of Inpari IR Nutri Zinc seeds and Inpari 42 seeds through farmer groups. Therefore those farmers get cost relief in obtaining these seeds.

The average use of solid fertilizers in the Inpari IR Nutri Zinc, Ciherang, and Inpari 42 paddy farming is $201,654 \mathrm{~kg}, 72,600 \mathrm{~kg}$, and $190,662 \mathrm{~kg}$, respectively. The highest average cost of solid fertilizer in Inpari 42 paddy farming is 207,685 IDR. Inpari IR Nutri Zinc paddy farming used more organic fertilizer, therefore the cost is lower. The average amount of use and cost of liquid fertilizer in Inpari IR Nutri Zinc paddy farming is higher than the Ciherang and Inpari 42 paddy farming, which is $488,062 \mathrm{~mL}$ with a cost of 11,976 IDR. 
The average pesticide cost in Inpari IR Nutri Zinc paddy farming is lower than the average pesticide cost in Ciherang and Inpari 42 paddy farming. Farmers rarely use pesticides, so the average pesticide cost in pesticide use is relatively small. According to research by Ratri and Yuliawati [11], the cost of pesticides does not affect income significantly. In addition, the amount of use of pesticides is also not a factor that can significantly increase paddy production [12].

The average use of non-family labor (TKLK) in Inpari IR Nutri Zinc, Ciherang, and Inpari 42 paddy farming is $8.76 \mathrm{HKO}, 6.20 \mathrm{HKO}$, and $8.98 \mathrm{HKO}$, respectively. The number of HKO of TKLK in Inpari IR Nutri Zinc paddy farming is less than the number of HKO of TKLK in Inpari 42 paddy farming. But, the cost of TKLK in Inpari IR Nutri Zinc paddy farming is higher than the cost of TKLK in Inpari 42 paddy farming. This is because the wholesale wages paid by farmer respondents to workers are different. The wages paid ranged from 40,000 IDR to 110,000 IDR per HKO.

The average cost of equipment depreciation in Inpari IR Nutri Zinc paddy farming is higher than the average equipment depreciation cost in Ciherang and Inpari 42 paddy farming, which is 34,803 IDR.

The average cost of land rent in Inpari 42 paddy farming is higher than the average cost of land rent in Inpari IR Nutri Zinc and Ciherang paddy farming. There are 20 percent of Inpari 42 paddy farmers who use leased land. Meanwhile, the average cost of production sharing of Ciherang paddy farming is higher than the average cost of production sharing of Inpari IR Nutri Zinc and Inpari 42 paddy farming. There are 40 percent of Ciherang paddy farmers who use the land with a production sharing system.

The average other costs of Inpari IR Nutri Zinc paddy farming are higher than the average other costs of Ciherang and Inpari 42 paddy farming, which is 173,814 IDR. Other costs consist of milling cost, nonfamily labor (TKLK) consumption, land tax, gasoline, purchase of sacks, and sprayer rental.

\subsection{Implicit Cost}

Implicit costs are costs that are not real incurred by farmers. However, the implicit costs are still taken into account in the activities of farming. The implicit costs in this study consist of fertilizer, pesticide, family labor (TKDK) costs, the rental value of own land, and the cost of own capital interest.

The average cost of fertilizer in Inpari 42 paddy farming is higher than the average cost of fertilizer in Inpari IR Nutri Zinc and Ciherang paddy farming, which is 60,667 IDR. The fertilizer used by farmers is organic fertilizer from their livestock manure. Therefore, the fertilizer is included in the implicit cost.

Table 6. Average Implicit Cost Per 1,000 $\mathrm{m}^{2}$ Per Paddy Planting Season

\begin{tabular}{|l|r|r|r|}
\hline \multirow{2}{*}{ Cost Type } & \multicolumn{3}{|c|}{ Cost (IDR) } \\
\cline { 2 - 4 } & Inpari IR Nutri Zinc & Ciherang & Inpari 42 \\
\hline Fertilizer & 40,514 & 39,167 & 60,667 \\
\hline Pesticide & 26,026 & 15,616 & 22,556 \\
\hline Family Labor (TKDK) & 245,139 & 231,415 & 288,979 \\
\hline Rental of Own Land & 300,000 & 250,000 & 250,000 \\
\hline Own Capital Interest & 27,249 & 27,481 & 27,490 \\
\hline Total & $\mathbf{6 3 8 , 9 2 8}$ & $\mathbf{5 6 3 , 6 7 9}$ & $\mathbf{6 4 9 , 6 9 2}$ \\
\hline
\end{tabular}

The average cost of pesticides in Inpari IR Nutri Zinc paddy farming is higher than the average pesticide cost in Ciherang and Inpari 42 paddy farming. The pesticides included in 
the implicit cost are organic pesticides obtained from government assistance channeled through the agricultural extension center (BPP) of Nanggulan Sub-district.

The average use of family labor in Inpari IR Nutri Zinc paddy farming is 4.09 HKO. The average use of family labor in Ciherang paddy farming is $3.91 \mathrm{HKO}$. The average use of family labor in Inpari 42 paddy farming is $4.98 \mathrm{HKO}$. Compared to the use of nonfamily labor (TKLK) in Inpari IR Nutri Zinc, Ciherang, and Inpari 42 paddy farming which is 8.76 $\mathrm{HKO}, 6.20 \mathrm{HKO}$, and $8.98 \mathrm{HKO}$, respectively, the use of family labor in Nanggulan Subdistrict is less than the use of non-family labor. In contrast to the results of the study of Milfitra et al. [13], the use of family labor in paddy farming is more than the use of nonfamily labor. The results of Ratri and Yuliawati's research [11], show that paddy farmers of Ciherang variety use more labor in the family, so the cost incurred is less than the cost of Mekongga paddy farmers who use more non-family labor.

The average rental value of own land in Inpari IR Nutri Zinc, Ciherang, and Inpari 42 paddy farming is $300,000 \mathrm{IDR}, 250,000 \mathrm{IDR}$, and 250,000 IDR per 1,000 $\mathrm{m}^{2} /$ planting season, respectively. Value of own land in Inpari IR Nutri Zinc paddy farming is the highest because the number of Inpari IR Nutri Zinc paddy farmers who use their land is more than the number of Ciherang or Inpari 42 paddy farmers who use their land. The number of Inpari IR Nutri Zinc paddy farmers who use their land is 60 percent.

The average interest cost of own capital in Inpari IR Nutri Zinc, Ciherang, and Inpari 42 paddy farming in Nanggulan District per $1,000 \mathrm{~m}^{2} /$ planting season is 27,249 IDR, 27,481 IDR, and 27,490 IDR, respectively. The percentage of own capital interest is $2 \%$ per paddy planting season or using a loan interest rate of $6 \%$ per year. It can be seen that the highest interest cost of own capital is in Inpari 42 paddy farming, which is 27,490 IDR because the explicit cost in Inpari 42 paddy farming is higher than the explicit cost in Inpari IR Nutri Zinc and Ciherang paddy farming.

\subsection{Total Cost, Revenue, Income, and Profit}

Table 7. Average of Total Cost, Production, Revenue, Income, and Profit Per 1,000 $\mathrm{m}^{2}$ Per Paddy Planting Season

\begin{tabular}{|l|r|r|r|}
\hline \multirow{2}{*}{ Description } & \multicolumn{3}{c|}{ Paddy Variety } \\
\cline { 2 - 4 } & $\begin{array}{c}\text { Inpari IR } \\
\text { Nutri Zinc }\end{array}$ & \multicolumn{1}{c|}{ Ciherang } & \multicolumn{1}{|c|}{ Inpari 42 } \\
\hline Explicit Cost (IDR) & $1,362,434$ & $1,374,039$ & $1,374,524$ \\
\hline Implicit Cost (IDR) & 638,928 & 563,679 & 649,692 \\
\hline Total Cost (IDR) & $2,001,362$ & $1,937,718$ & $2,024,216$ \\
\hline $\begin{array}{l}\text { Paddy Production Harvested Dry Grain } \\
\text { (GKP) (kg) }\end{array}$ & 499,421 & 607,540 & 595,97 \\
\hline Selling Price (IDR/kg) & 4,364 & 4,191 & 4,281 \\
\hline Revenue (IDR) & $2,179,575$ & $2,545,940$ & $2,551,111$ \\
\hline Income (IDR) & 817,141 & $1,171,901$ & $1,176,587$ \\
\hline Profit (IDR) & 178,213 & 608,222 & 526,895 \\
\hline
\end{tabular}

Total cost is the sum of the explicit cost and the implicit cost. In Table 6, it can be seen that the highest total cost is in Inpari 42 paddy farming is 2,024,216 IDR.

The result of study Arifin et al. [14], the total cost of rice farming reach 3,641,544.97 IDR/ha and income or profit reach 10,263,411.70 IDR/ha. According to Heryono et al. [15] in farmer group member, the cost of rice farming reach 12,691,000 IDR/ha and for the nonmember is $12,548,000 \mathrm{IDR} / \mathrm{ha}$. Therefore, the total cost of paddy farming in Nanggulan Sub-district is classified as high. 
Table 8. Paddy Production

\begin{tabular}{|l|r|r|r|}
\hline \multirow{2}{*}{ Description } & \multicolumn{3}{|c|}{ Paddy Production (tons/ha) } \\
\cline { 2 - 4 } & Inpari IR Nutri Zinc & Ciherang & Inpari 42 \\
\hline $\begin{array}{l}\text { Production Potential in } \\
\text { Milled Dry Grain (GKG) }\end{array}$ & 9.98 & 7 & 10.58 \\
\hline $\begin{array}{l}\text { Average Production in } \\
\text { Milled Dry Grain (GKG) }\end{array}$ & 6.21 & $5-7$ & 7.11 \\
\hline $\begin{array}{l}\text { Average Production in } \\
\begin{array}{l}\text { Milled Dry Grain (GKG) } \\
\text { in Nanggulan Sub- } \\
\text { district }\end{array}\end{array}$ & 4.03 & & 4.81 \\
\hline
\end{tabular}

The average production of Inpari IR Nutri Zinc paddy farming in Nanggulan District is still lower than the average production of Ciherang and Inpari 42 paddy farming. The result shows that the production of Inpari IR Nutri Zinc, Ciherang, and Inpari 42 paddy farming are still below the average yield and productivity potential according to the Indonesian Center for Paddy Research (BBPadi). The average yield of Inpari IR Nutri Zinc is 6.21 tons/ha GKG with a potential of 9.98 tons/ha GKG according to BBPadi. While the result of the study, the average production of Inpari IR Nutri Zinc paddy farming in Nanggulan Sub-district is $499.42 \mathrm{~kg} / 1,000 \mathrm{~m}^{2} \mathrm{GKP}$ or 4.99 tons/ha GKP or equivalent to $4.03 \mathrm{tons} / \mathrm{ha}$ GKG. The average yield of Ciherang is 5-7 tons/ha GKG with a potential yield of 7 tons/ha GKG according to BBPadi. While the result of the study, the average production of Ciherang paddy farming in Nanggulan Sub-district is $607.54 \mathrm{~kg} / 1,000 \mathrm{~m}^{2}$ GKP or 6.07 tons/ha GKP or equivalent to 4,91 tons/ha GKG. The average yield of Inpari 42 is 7,11 tons/ha GKG with a potential yield of 10,58 tons/ha GKG according to BBPadi. Meanwhile, as a result of the study, the average production of Inpari 42 paddy farming in Nanggulan Sub-district is $595,97 \mathrm{~kg} / 1.000 \mathrm{~m} 2$ GKP or 5.95 tons/ha GKP or equivalent to 4.81 tons/ha GKG. According to BPS [16], the conversion of GKP to GKG in DIY Province is 80.87 percent.

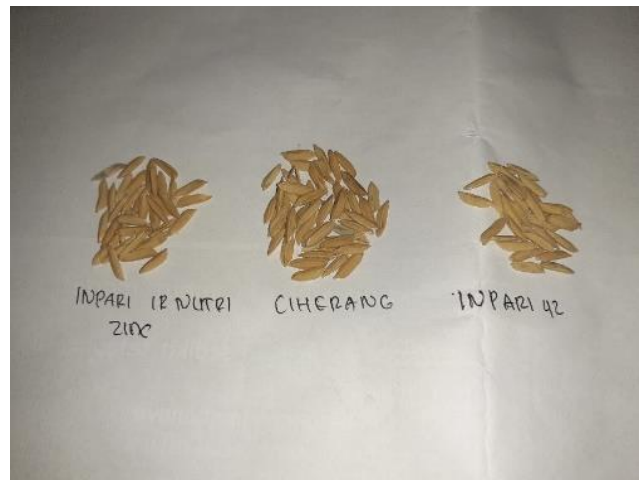

Fig. 1. Milled Dry Grain (GKG)

Statement Based on farmer respondents' and researchers' observations, the size of Inpari IR Nutri Zinc and Inpari 42 paddy grains is smaller than Ciherang paddy grains. In line with the results from BPPadi, the weight of 1,000 grains of Inpari IR Nutri Zinc is 24.60 grams. The weight of 1,000 grains of Ciherang is 27-28 grams. While the weight of 1,000 grains of Inpari 42 is 24.41 grams.

According to Sary et al. [17], major determinants significantly to increase paddy production in the wet season or the dry season include seeds, fertilizers, and hire labor. The 
study result of Gözener [12], the production factors which have a positive sign coefficient are the used male labor amount, fertilizer amount, and seed amount.

Based on the results of the One Way Anova analysis test, the average income of the significant results is $0.149>0.10$, which means that there is no significant difference in the average income between Inpari IR Nutri Zinc, Ciherang, and Inpari 42 paddy farming. While One Way Anova analysis test, the average profit of the significance $0.004<0.10$, which means that there is a significant difference in the average profit in the farming of Inpari IR Nutri Zinc, Ciherang, and Inpari 42 paddy.

Table 9. LSD Test Results of Average Profit

\begin{tabular}{|l|r|}
\hline Description & Significance \\
\hline LSD Test & \\
-Inpari IR Nutri Zinc-Ciherang & 0.002 \\
-Inpari IR Nutri Zinc-Inpari 42 & 0.010 \\
•Inpari 42-Ciherang & 0.538 \\
\hline
\end{tabular}

Based on Table 9, the results of the LSD test of the difference in average profit shows that there is a significant difference in the average profit in Ciherang paddy farming with Inpari IR Nutri Zinc paddy farming and Inpari 42 paddy farming with Inpari IR Nutri Zinc paddy farming. This is because the results of the LSD test significance are smaller than $10 \%$ alpha.

\subsection{Feasibility Analysis}

Knowing the feasibility of farming in terms of $\mathrm{R} / \mathrm{C}$, land productivity, labor productivity, and capital productivity.

Table 10. Feasibility Analysis Per $1,000 \mathrm{~m}^{2}$ Per Paddy Planting Season

\begin{tabular}{|l|r|r|r|}
\hline \multirow{2}{*}{ Description } & \multicolumn{3}{|c|}{ Paddy Variety } \\
\cline { 2 - 4 } & Inpari IR Nutri Zinc & Ciherang & Inpari 42 \\
\hline R/C & 1,095 & 1,333 & 1,269 \\
\hline Land Productivity (IDR/m ${ }^{2}$ ) & 545 & 913 & 860 \\
\hline Labor Productivity (IDR/HKO) & 179.362 & 326.812 & 371.715 \\
\hline Capital Productivity (\%) & 25,028 & 67,319 & 74,284 \\
\hline
\end{tabular}

Based on Table 10 shows that the feasibility of Inpari IR Nutri Zinc paddy farming is still lower than the feasibility of Ciherang and Inpari 42 paddy farming in terms of $\mathrm{R} / \mathrm{C}$, land productivity, labor productivity, and capital productivity.

$\mathrm{R} / \mathrm{C}$ on the three varieties of paddy farming is said to be feasible for cultivation. This is because the $\mathrm{R} / \mathrm{C}$ result is more than one. This means that revenue obtained by farmers is more than the total cost incurred by farmers in paddy farming.

Based on Table 11, it is known that the significance of the One Way Anova test is $0,003<0,10$, which means that there is a difference in the average $\mathrm{R} / \mathrm{C}$ in the paddy farming of Inpari IR Nutri Zinc, Ciherang, and Inpari 42. Judging from the results of the significance of the LSD test, there is a difference in the average $\mathrm{R} / \mathrm{C}$ in the Ciherang paddy farming with Inpari IR Nutri Zinc paddy farming and Inpari 42 paddy farming with Inpari IR Nutri Zinc paddy farming. This is because the results of the LSD test significance are smaller than $10 \%$ alpha. 
Table 11. One Way Anova Test Result and LSD Test Result of Average R/C

\begin{tabular}{|l|r|}
\hline Description & Significance \\
\hline One Way Anova Test & 0.003 \\
\hline LSD Test & \\
•Inpari IR Nutri Zinc-Ciherang & 0.001 \\
•Inpari IR Nutri Zinc-Inpari 42 & 0.015 \\
•Inpari 42-Ciherang & 0.358 \\
\hline
\end{tabular}

The cost of renting land in Nanggulan District is approximately 1,500,000 IDR per $1,000 \mathrm{~m}^{2}$ per year or 500 IDR per $\mathrm{m}^{2}$ per planting paddy season. Therefore, it can be said that land productivity in Inpari IR Nutri Zinc, Ciherang, and Inpari 42 paddy farming is feasible to cultivate. This is because the average land productivity in the three varieties of paddy farming is more than the cost of renting land in Nanggulan District. This means that instead of renting own land by farmers to others, it is better to conduct paddy farming.

Table 12. One Way Anova Test Result and LSD Test Result of Average Land Productivity

\begin{tabular}{|l|r|}
\hline Description & Significance \\
\hline One Way Anova Test & 0.086 \\
\hline LSD Test & \\
•Inpari IR Nutri Zinc-Ciherang & 0.041 \\
•Inpari IR Nutri Zinc-Inpari 42 & 0.079 \\
•Inpari 42-Ciherang & 0.764 \\
\hline
\end{tabular}

Based on Table 12, it is known that the significance of the One Way Anova test is 0.086 $<0.10$ which means that there is a difference in the average land productivity in Inpari IR Nutri Zinc, Ciherang, and Inpari 42 paddy farming. Judging from the results of the LSD test significance, there is the difference significantly between in average land productivity in Ciherang paddy farming with Inpari IR Nutri Zinc paddy farming and Inpari 42 paddy farming with Inpari IR Nutri Zinc paddy farming. This is because the results of the LSD test significance are smaller than $10 \%$ alpha.

The wages of farm labor in Nanggulan Sub-district range from 40,000 IDR to 110,000 IDR. The results show that paddy farming of the three varieties which is seen from the labor productivity was feasible to conduct. This is because the labor productivity is higher than the wages of farm labor in the area. This means that paddy farming activities better be carried out by workers from the family.

Table 13. One Way Anova Test Result and LSD Test Result of Average Labor Productivity

\begin{tabular}{|l|r|}
\hline Description & Significance \\
\hline One Way Anova Test & 0.089 \\
\hline LSD Test & \\
•Inpari IR Nutri Zinc-Ciherang & 0.105 \\
•Inpari IR Nutri Zinc-Inpari 42 & 0.036 \\
•Inpari 42-Ciherang & 0.618 \\
\hline
\end{tabular}

Based on Table 13, it is known that the significance of the One Way Anova test is 0.089 $<0.10$ which means that there is a difference in the average labor productivity in the Inpari IR Nutri Zinc, Ciherang, and Inpari 42 paddy farming. Judging from the results of the LSD test significance, there is the difference significantly in the average labor productivity in Ciherang paddy farming with Inpari IR Nutri Zinc paddy farming. This is because the results of the LSD test significance are smaller than $10 \%$ alpha. 
The percentage of the use loan interest rate is $6 \%$ per year or $2 \%$ per paddy planting season. Therefore, the capital productivity in the three varieties of paddy farming is feasible to conduct. This is because the capital productivity of the paddy farming of the three varieties is higher than the percentage of the loan interest rate in the area. If farmers borrow capital for paddy farming, farmers can return the loan capital from the income of farming. The results of the One Way Anova test show that the significance is $0.105>0.10$, which means that there is no difference significantly between in the average of capital productivity in Inpari IR Nutri Zinc, Ciherang, and Inpari 42 paddy farming.

\section{Conclusion and Recommendation}

The average cost of Inpari IR Nutri Zinc, Ciherang, and Inpari 42 paddy farming per 1,000 $\mathrm{m}^{2}$ per planting season in Nanggulan Sub-district is 2,001,362 IDR, 1,937,718 IDR, and 2,024,216 IDR, respectively. The average revenue of Inpari IR Nutri Zinc, Ciherang, and Inpari 42 paddy farming per $1,000 \mathrm{~m}^{2}$ per planting season is $2,179,575 \mathrm{IDR}, 2,545,940$ IDR, and 2,551,111 IDR, respectively. The average income of Inpari IR Nutri Zinc, Ciherang, and Inpari 42 paddy farming per $1,000 \mathrm{~m}^{2}$ per planting season is 817,141 IDR, $1,171,901$ IDR, and 1,176,587 IDR, respectively. The average profit of Inpari IR Nutri Zinc, Ciherang, and Inpari 42 paddy farming per $1,000 \mathrm{~m}^{2}$ per planting season is 178,213 IDR, 608,222 IDR, and 526,895 IDR, respectively.

Income, profit, and feasibility of Inpari IR Nutri Zinc paddy farming in terms of R/C, land productivity, labor productivity, and capital productivity are still lower than the feasibility of Ciherang and Inpari 42 paddy farming. Average of $\mathrm{R} / \mathrm{C}$ per $1,000 \mathrm{~m}^{2}$ per planting season of Inpari IR Nutri Zinc, Ciherang, and Inpari 42 paddy farming in Nanggulan District is $1,095,1,333$, and 1,269 respectively. The average land productivity of Inpari Rice IR Nutri Zinc, Ciherang, and Inpari 42 paddy farming per $\mathrm{m}^{2}$ per planting season in Nanggulan District is 545 IDR, IDR 913, and 860 IDR, respectively. The average labor productivity of Inpari IR Nutri Zinc, Ciherang, and Inpari 42 paddy farming in Nanggulan District is 179,362 IDR/HKO, 326,812 IDR/HKO, and 371,715 IDR/HKO, respectively. The average capital productivity of Inpari IR Nutri Zinc, Ciherang, and Inpari 42 paddy farming per $1,000 \mathrm{~m}^{2}$ per planting season in Nanggulan District is $25.028 \%$, $67.319 \%$, and $74.284 \%$, respectively.

Based on the study result, Inpari IR Nutri Zinc Paddy Farming has low feasibility, revenue, income, and profit, relatively because of low paddy production. Therefore the recommendation is optimizing significant inputs which can increase paddy production such as give more attention to the use of fertilizers, the use of the seed, and the use of labor to carry out paddy farming activities [18-21]. In addition, it is necessary to conduct a deeper study related to the environmental conditions needed by Inpari IR Nutri Zinc paddy plant to produce more such as the amount also kind of nutritions are needed by Inpari IR Nutri Zinc paddy plant and climate element factors those are matched to cultivate Inpari IR Nutri Zinc plant [22].

Acknowledgement. Author want to thank to Dr. Ir. Triwara Buddhi Satyarini and Ir. Lestari Rahayu, MP. for guiding and supervising this study.

\section{References}

1. Y. I. Nasution, Z. Lubis, and A. Rahman, J. AGRISAINS J. Ilm. Magister Agribisnis 1, 190 (2019).

2. BBPadi, Balai Besar Penelit. Tanam. Padi Balitbangtan Kementeri. Pertan. (2019). 
3. U. Abay, Swadaya Media Bisnis Pertan. (2020).

4. H. Susanto, RRI Yogyakarta (2021).

5. BPS Kabupaten Kulon Progo, Kabupaten Kulon Progo Dalam Angka 2019 (CV. Magna Raharja Tama, Yogyakarta, 2019).

6. M. Ismail, L. E. Pakpahan, R. Jaya, Asis, and Husaini, in Strateg. Ketahanan Pangan Masa New Norm. Covid-19 (2020), pp. 103-110.

7. I. Susanti, F. N. Azis, and M. Saeri, Gontor AGROTECH Sci. J. 6, 527 (2020).

8. S. Loeb, S. Dynarski, D. McFarland, P. Morris, S. Reardon, and S. Reber, Descriptive Analysis in Education: A Guide For Researchers (2017).

9. L. Rahayu, E. I. N. Anggraeni, and T. Buddhi, in Semin. Nas. (2018), pp. 83-92.

10. Soekartawi, Analisis Usahatani (Penerbit Universitas Indonesia, Jakarta, 2002).

11. M. A. Ratri and Yuliawati, Agritech J. Fak. Pertan. Univ. Muhammadiyah Purwokerto 21, 1 (2019).

12. B. Gözener, 154 (2016).

13. W. Milfitra, K. M. Zain, and L. Fitriana, Analisis Pendapatan Usahatani Padi Sawah Di Desa Rokan Koto Ruang Kecamatan Rokan IV Koto Kabupaten Rokan Hulu, Universitas Pasir Pengaraian, 2016.

14. Arifin, A. A. Wahditiya, Nirawati, and M. A. Biba, Int. J. Sci. Technol. Res. 7, 52 (2018).

15. M. Heryono, I. Nugroho, and R. Hanafie, Agric. Socio-Economics J. 16, 31 (2016).

16. BPS, Survei Konversi Gabah Ke Beras 2018 (Badan Pusat Statistik, 2018).

17. S. Sary, Y. Wen, S. Darith, and N. V. Chand, J. Agrociencia 54, 78 (2020).

18. Z. Rozaki, Indardi, Triyono, I. Salassa, and R. B. Nugroho. Farmers' responses to organic rice farming in Indonesia: Findings from central Java and south Sulawesi. Open Agric. 2020, 5, 703-710.

19. Z. Rozaki, O. Wijaya, and C. K. Wardana. Agriculture developement based on regional potency in kulonprogro regency. IOP Conf. Ser. Earth Environ. Sci. 2021, 683.

20. Triyono, N. Rahmawati, and Z. Rozaki. Sustainable value of rice farm based on economic efficiency in Yogyakarta, Indonesia. Open Agric. 2021, 6, 563-572.

21. Winarno, B. Neoliberal Policy of Indonesia's Agricultural Revitalization. Jurnal Hubungan Internasional. 2016, 5, 31-39.

22. D. Firdaus, RS. Natawidjaja, and M Rachmady. Strengthening of the Formal Complementary Paddy Seeding System and Informal to Fulfill Demand of Quality Paddy Seeds and to Develop Seed Farming Business in West Java. E3S Web of Conferences 142, 06001 (2020) 